Caribbean Routes: Ethnographic Experiences, Theoretical Challenges, and the Production of Knowledge

\title{
Materiality, affection, personhood: on sacrifice in the worship of the goddess Kali in Guyana
}

\author{
Marcelo Moura Mello'
}

'Universidade Federal da Bahia, Departamento de Antropologia e Etnologia, Salvador/BA, Brasil

\begin{abstract}
This paper describes the ritual procedures associated with animal sacrifice in the worship of the Hindu goddess Kali in Guyana, formerly British Guiana. Animal sacrifice is explored through questions relating to materiality, personhood and the mutual permeability of persons and objects. The aim is to advance an interpretation based on native conceptions regarding the potential effects of the exchange and circulation of substances between devotees of the goddess Kali, Hindu deities, and ritual artefacts.
\end{abstract}

Key words: Sacrifice; Worship of the goddess Kali; Guyana; Materiality; Personhood. 


\section{Materialidade, afetação e pessoalidade: sobre o sacrifício no culto à deusa Kali na Guiana}

\section{Resumo}

O texto descreve procedimentos rituais associados ao sacrifício de animais no culto à deusa hindu Kali na Guiana, antiga Guiana Inglesa. O sacrifício de animais é pensado à luz de questões relativas à materialidade, a pessoalidade e à permeabilidade de pessoas e objetos umas às outras. Busca-se avançar uma interpretação centrada nas concepções nativas sobre os potenciais efeitos da troca e da circulação de substâncias entre devotos da deusa Kali, divindades hindus. e artefatos rituais.

Palavras-chave: Sacrifício; Culto à Kali; Guiana; Materialidade; Pessoalidade. 


\title{
Materiality, affection, personhood: on sacrifice in the worship of the goddess Kali in Guyana'
}

\author{
Marcelo Moura Mello
}

In this article I describe sacrificial ritual acts in the worship of the Hindu goddess Kali in Guyana, formerly British Guiana. I present a specific case in order to highlight the non-material elements involved in the manipulation of ritual artefacts, which can be affected by the transmission of the states of being of spiritual entities, bodily substances and what is called by my interlocutors of affection $(s)^{2}$ of human and nonhuman persons. Far from taking sacrifice as a self-contained act or reducing it to a modality of reciprocal relations between humans and divinities, I seek to show how divinities, humans, animals and ritual artefacts are permeable to each other.

The text is an exploratory attempt to incorporate anthropological approaches produced on other ethnographic regions into the core discussions of Caribbean scholarship, especially with regard to the religious practices of Indo-Caribbean populations. I begin by presenting some basic elements of Kali worship in Guyana. Next, I describe in more detail events that occurred at one religious festival. Finally, I foreground issues relating to materiality, substance and personhood.

\section{Kali worship and the sacrifice of animals}

Transplanted to Guyana by Indians who moved to the country as indentured labourers between 1838-1917, in the aftermath of the abolition of black slavery in the British Caribbean in $1834,{ }^{3}$ Kali worship, or Kali Puja, is characterized by healing practices to cure diseases with a physical and spiritual origin. Each week, Hindu deities (deotas) manifest themselves in the bodies of religious experts in order to heal people, occasions on which they reveal, through verbal acts, the causes of the problems afflicting devotees, as well as to prescribe the acts of devotion to be performed by those consulting them.

Through distinct practices of devotion to the deities, men and women seek to cure themselves of diseases and misfortunes, improve their lives, including materially, and obtain blessings, such as begetting a child. The rites of Kali worship are called pujas: that is, the manifestations of belief and submission to the Hindu deities through prayers and offerings. Eventually, works are performed by priests and other members of the temple in the houses of devotees, normally to counterbalance the effects of the actions of spirits and other malign beings, or those of witchcraft.

\footnotetext{
1 Acknowledges: This research was possible thanks to funding schemes of the Universidade Federal da Bahia and to the Graduate Program of Social Anthropology of the Museu Nacional, Universidade Federal do Rio de Janeiro. Many thanks to David Rodgers, who translated this article, and to Cauê Fraga Machado, for his suggestions.

2 Use of italics in this article indicates native terms.

3 Almost 240,00o Indians migrated between 1838-1917 to what was then British Guiana. For more details on Indian indentured labour, see: Bahadur 2014; Connoly 2019; Laurence 1994; Look Lai 1993; Smith 1959; Tinker 1993 [1974].
} 
In the temple where I conducted most of my observations, Blairmont, ${ }^{4}$ seventeen Hindu divinities are worshipped, six of whom manifest in humans. The culminating point of the weekly rites of Kali worship precisely involves the invocation of gods and goddesses in the bodies of certain religious specialists called marlos. Marlos are men and women whose bodies serve as vehicles for the revelations and therapeutic treatments performed by divinities. Manifestations of these deities are not uniform since they unfold at specific levels: more or less full, deep or pure. In reality, the shakti (power) of the deotas is never fully propagated since human bodies can stand only a small fraction of this power. But gradations do exist: someone impure is incapable of standing a manifestation and only through training is it possible to develop it.

Kali devotees are mostly descendants of Indians living in impoverished rural areas of Guyana's Atlantic coastal region who self-identify as Hindus. Participation and attendance in the rites are not limited to Hindus, though. Muslims, Christians and Afro-Guyanese people also take part, as well as sanatanists, that is, members of Sanatan Dharma, a Hindu tradition self-proclaimed as orthodox, Brahmin and Northern Indian in origin. ${ }^{5}$ This aspect is important since Kali worship tends to be associated exclusively with the so-called Madrasi, descendants of Southern Indians. ${ }^{6}$ The reasons for the association between Kali worship and the Madrasi are complex. Suffice to say that in their efforts to develop Hinduism in an asymmetric colonial setting ${ }^{7}$ founded on Christian values, members of Sanatan Dharma sought to legitimize their religion by dissociating themselves from practices deemed morally suspect, such as possession and animal sacrifice, attributing them to the Madrasi (see, among others, Khan 2004; McNeal 2011; Stephanides \& Singh 2000; Vertovec 1996; Younger 2010).

Whatever the case, any person, irrespective of origin or religious affiliation, may visit Kali temples, although consultations with deities and presence in the pujas depends above all on the strict observance of fasting. In other words, to attend a temple, the person must spend the previous three days avoiding sexual relations, the ingestion of foods of animal origin, or the consumption of recreational drugs and alcoholic drinks. Menstruating women ${ }^{8}$ cannot accompany the rites, nor those who have had contact with new-borns or the recently deceased. In their day-to-day lives, humans are in relation with impure persons, substances and beings. Consequently, they must adhere to certain indispensable prescriptions if they are to enter into contact with the deities, keeping themselves immune to the affectations arising from diverse kinds of impurity. I return to this point below. Divine power also produces effects in persons, sometimes negative, especially at moments considered critical and dangerous, such as the sacrifice of animals.

Dialogues about animal sacrifice are extremely common among Kali worshippers for a series of reasons, including the concern, especially among priests, to ensure that sacrifices are conducted correctly. Put otherwise, sacrificial practices must conform to the precepts of sacred Hindu writings. This emphasis is partly a response to the stigmatization of Kali worship in Guyana, which is normally associated with witchcraft, the devil and the evil. Such stigmas are not exclusive to Christians. Many Sanatanists see Kali worship as a distorted version of Hinduism, precisely because of practices like animal sacrifice, which, they argue, contravene the Hindu principle of non-violence.

\footnotetext{
4 I conducted ten months of intensive fieldwork in Guyana between 2010-2012, which resulted in my dissertation in social anthropology (Mello 2014). In 2018 I undertook brief visits to the country. My observations were concentrated on one temple, Blairmont, and I interacted mostly with its members especially, but not exclusively, young and middle-age men. The data analysed in this article were gathered between September 2011 and February 2012 , a period in which my fieldwork was focused primarily on the Blairmont temple. Among other things, I not only observed the preparations for religious feasts, but also took an active part in them, including the Big Puja.

5 During the indenture system, labourers from India embarked from the ports of Calcutta (Kolkatta) in the north of the country and Madras (Chennai) in the south. More than $85 \%$ of the hired workers who disembarked in Guyana came from the north of the subcontinent (Look Lai 1993; Smith 1959).

6 Southern Indian Hindu traditions in the Caribbean were continuously shaped through exchanges with other Hindu practices of North Indian origin. Besides Guyana and Trinidad and Tobago, Indian Southern Traditions are still vibrant in Suriname, Guadalupe, and Martinique.

7 Guyana gained its independence from the United Kingdom in 1966.

8 Menstruation does not entirely preclude the presence of women in the temple, so long as they have no contact with altars, ritual objects or cooking utensils. Even so, the presence of women in this state is potentially dangerous, especially at critical moments like sacrifice.
} 
My interlocutors not only cite diverse Hindu scriptures in which animal sacrifice is mentioned, they also stress that some divine forms need to be nourished with life and blood to realize their work. Form is a central concept in Hinduism as a whole (see Brubaker 1978; Eck 1998) and for Hindus from different traditions in Guyana. Essentially, just one God exists, a Primordial being who manifests itself in different forms. For my interlocutors, over history, this Being, Kali, assumed these distinct forms in response to the specific needs of the humans and gods. This is why there are so many divinities, which are ultimately forms of this one Supreme Being, simultaneously different and equal to the latter - hence the phrase recurrently expressed by Hindus in Guyana: all the divinities are the same. ${ }^{9}$

This principle is actualized in a differentiating mode depending on which divinity is involved. For example, the god Khal Bhairo is defined as a dark form of the god Shiva. Khal Bhairo is not singular and can assume diverse forms: dark, ferocious, voracious, perverse, or, conversely, amenable. All the divinities possess both terrible and benign forms, but some of them, like Khal Bhairo, are thought to be closer to one of these poles, characterized either by their disruptive, implacable and ferocious behaviour, or, on the contrary, by their docile temperament, as in the case of the goddess Lakshmi. Khal Bhairo may sometimes assume a benign form and Lakshmi a malign form, while certain divinities tend to manifest in specific forms whose main attributes encompass others.

In the ritual context, this means that the more generic attributes of each deota determine which items should be offered, which problems a divinity can resolve and with which beings she relates. The goddess Mariamma, for example, though ferocious and vengeful, is simultaneously benign, associated with healing, including pestilent and contagious diseases. For this and other reasons, goat sacrifices should be made to Mariamma, both to honour her deeds and because of the goddess's need to be nourished in order to bear the impurities of sick and weak bodies. On the other hand, Mariamma does not deal with everything. Sicknesses caused by spells and spirits are cured by Kateri, a dark form of Mariamma capable of subjugating malign beings and removing the nastiest impurities from human bodies. For this very reason, Kateri consumes alcohol and smokes cigarettes during the pujas because of the permanent contract with impurities, consuming intoxicating substances precisely to becomes less immune to them. Khal Bhairo, in turn, is a central figure in mythic battles against demons and is Mariamma's guardian, repelling any threat to her well-being. As essentially a warrior god, Khal Bhairo must be constantly fed with goats and cockerels.

Another deity central to Kali worship, including its mythology, is Bhadra Kali. It is told that thousands of years ago the demon Raktabija was graced with a boon from the god Shiva: each time a drop of his blood hit the soil, another Raktabija would emerge. Imbued with this power, the demon rebelled against the gods and tried to subjugate them. The latter tried to fight back, but each injury inflicted on the demon generated more demons until finally an uncountable number of Raktabijas had emerged. Alarmed, the gods first turned to the warrior goddess Durga, whose ferocious drive made the situation even worse, since the slaughter she unleashed generated thousands more demons. Enraged, Bhadra Kali emerged from her, a terrible form of the (already) ferocious Durga. Bhadra Kali, possessing diverse weapons, also had another talent: she could prevent Raktabija's blood from striking the soil, sucking up each drop produced by the latter's mortal wounds. As the battle unfolded, the goddess supplanted countless demons. In this way, Bhadra Kali acquired the taste for blood and began to destroy other things and beings, including the benign. The universe was once again in danger, this time due to Bhadra Kali. Mad with rage, the goddess destroyed everything and everyone. Only after Shiva, her consort, placed himself at her feet, as though he was one of her victims, did Bhadra Kali come to her senses and cease her destruction.

9 As Eck remarked: "Hindu thought is most distinctive for its refusal to make the one and the many into opposites. For most, the manyness of the divine is not superseded by oneness. Rather, the two are held simultaneously and are inextricably related” (Eck 1998: 28). 


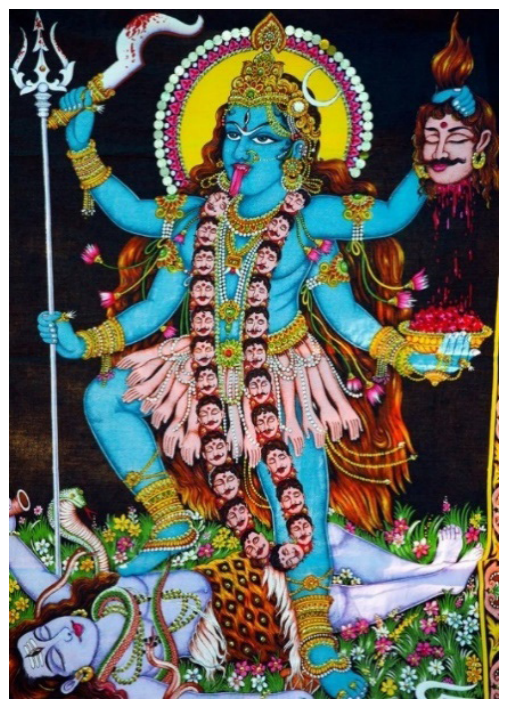

I cannot analyse this myth in close detail here. However, I highlight the fact that the potentially intoxicating effect of blood is clear in this myth. Blood is imbued with qualities that indicate what Carsten (2013) calls an "excess of potentiality," associated in Blairmont with impurity, vitality, instability and danger. Raktabija, the demon who put the very existence of the universe in jeopardy, self-reproduces with the drops of blood that spill on the ground. The emergence of more and more Raktabijas eventually leads to the engendering of a terrible divine form, Bhadra Kali, who subjugates her enemies and becomes enraptured with death, uncontrollable, relentless, thirsting for blood. Not by chance, in the Blairmont temple Bhadra Kali does not receive any pujas. She has no altar and is never invoked, although she manifests sometimes in people during rites. Her temperament, as potent as it is unstable, is inherently dangerous. Invoking her would imply continuous offerings and demand training for her to manifest in people's bodies - an exercise not just risky but futile since no human can stand the power of Bhadra Kali for very long in their body.

While the reflections and comments surrounding animal sacrifices are partly provoked in response to stigmas and criticisms of outsiders, not everything can be reduced to the mobilization of discourses and knowledge to legitimize religious practices considered morally suspect by others. In scenarios in which notions of purity, orthodoxy, correctness and authenticity are mobilized, the legitimization of religious practices (see Khan 2004) and mythic themes are fundamental since they foreground reflections on the potential effects arising from the ingestion, exchange and circulation of substances.

The incidence of sacrifices relates to mythic themes, to the possible effects of the torrents of blood. Indeed, some divinities drink the blood of sacrificed animals via their human vehicles. In videos distributed on platforms like YouTube it is not unusual to find scenes in which Kali worshippers in Guyana, when manifesting a deity, seize the heads or even the dismembered bodies of goats in order to slurp their blood. Signals emitted by divinities during the manifestation give proof of this connection: Bhadra Kali, specifically, sticks out her tongue when she manifests, which expresses her desire for blood. Put otherwise, some deities are nourished by blood, extracting this substance and renewing some of their power through it.

During my research I never witnessed this kind of scene, since temple assistants do not allow the deities' manifestations any access to the recently sacrificed animals. Such vigilance is constant, especially in religious festivals, occasions where shakti is disseminated with greater intensity. Consequently, in the two major annual religious festivals, the Small Puja and the Big Puja, dozens of men join hands and form a circle between the sacrifice officiants and worshippers, preventing any divine frenzy. Normally, a standardized explanation is given for the circle: the objective is to protect the audience since the risk of injury is always present. 
The circle certainly aims to safeguard the physical integrity of the audience, while it also avoids the occurrence of acts and gestures labelled wild and primitive by the Sanatanists..$^{10}$ In any event, for members of Blairmont, the sacrifices demand precautions and special care. After all, with the consummation of the sacrifices, the divine manifestations burst out more strongly, impelling their human vehicles towards the animals, and amid all this commotion, extremely sharp objects are wielded with force.

Sacrifice is a critical moment, providing leeway for unforeseen and potentially harmful effects. Not by chance, in the conversation with my interlocutors or in the dialogues between peers, the notion of affection is frequently enunciated. As we shall see below, subsequently illustrated through the reconstruction of a specific case, animal sacrifice is just one of the transactional modalities between humans and deities, although it channels extremely potent forces and energies. I turn now to a more detailed description of the practices that precede, and involve, animal sacrifices, highlighting the manipulation of ritual objects.

\section{Caring for animals, manipulating objects and powers}

In Kali worship, animal sacrifice is essentially necessary in five different circumstances: to increase the efficacy of a healing treatment and/or as part of someone's devotion; to give thanks for some blessing; to follow, or revive, a family tradition (a home or family puja); during religious festivals; and to propitiate the masters of the land, that is, Dutch spirits. ${ }^{11}$ I shall not explore all these ritual modalities in detail here. I simply call attention to the fact that sacrifices conducted outside the temple are considered different to those realized inside, both in terms of their intended purposes - animals are not sacrificed for spirits in the temple, for instance - and in terms of their potential effects. Concerning the last point, it should be emphasized that temples are pure spaces where, ideally, all the frequenters have abstained. Private spaces, on the other hand, are necessarily contaminated, given the circulation of several persons, objects, and foodstuff. Although abstinence should be followed for some days prior to performing ritual work in a domestic context, houses are permanently impure spaces, especially those inhabited by malign beings - something commonplace in the country, in fact.

The sacrifices are consummated inside the temple during the weekly Sunday service and in festivals for specific divinities, namely Sangani, Munispren, Mariamma and Khal Bhairo. The goddess Kateri is offered chickens, which are not killed, however, but released after the ritual. ${ }^{12}$ People whose worship demands the offering of life, as people say, schedule the date of the sacrifice in conversation with the priest. Except for specific occasions, notably vegetarian deity festivals and the annual celebration of ancestors (Pitri-Paksha), sacrifices in principle can be consummated on any day of the religious service. Sacrifices are not made for trivial motives, my interlocutors emphasized, but in response to divine prescriptions and to assist someone with problems and/or wishing to give thanks for past blessings granted by divinities.

\footnotetext{
10 When I met Penny, one of the killer-men of Blairmont, in the first months of my research in 2010, he told me that Blairmont was not a sweet temple, that is, a temple in which only vegetarian offerings were made. In his definition, Blairmont was a root temple, which followed the teachings of the Old Indians. Blairmont was a pure place, according to him, because nasty things were not allowed, such as letting the manifestations consume blood or pouring blood in the altars.

11 Spirits of the Dutch, the first European settlers of the country. Vengeful, cheaters, self-interested, false and dangerous, these spirits are considered by residents of the country's coastal region to be the true masters of the land, or boundary masters, possessing prerogatives over the places where they lived in the past, and affecting, malevolently, the life of contemporary Guyanese residing in these areas, above all in locations where sugar plantations once existed or still exist. See Mello (2020) and Williams (1990).

12 In the so-called night works, however, performed in the area outside the temple, black roosters are sacrificed for Kateri. Like Sangani, to whom roosters are also offered in this area, Kateri deals with malignant beings. The night works are also performed for (even) darker forms of Kateri and Sangani.
} 
Sacrifices are not one-way. The divinities, by means of the murtis, ${ }^{13}$ sculptured forms of the deities, consume the spiritual matter of all offerings placed on their altars. The leftovers of the offered items become sacred, infused with divine power, shakti. At the end of the weekly rituals, prasad, blessed food, is ingested by people who incorporate part of the divine power into themselves, energizing, strengthening and purifying their bodies and their internal dispositions. Since prasad is always consumed, the worshippers absorb the divine essence itself into their bodily persons (Nabokov 2000: 9). In sum, sharing foods and being fed by the murtis amounts to a combination of worship and mutual feeding (see Carsten 2000: 22).

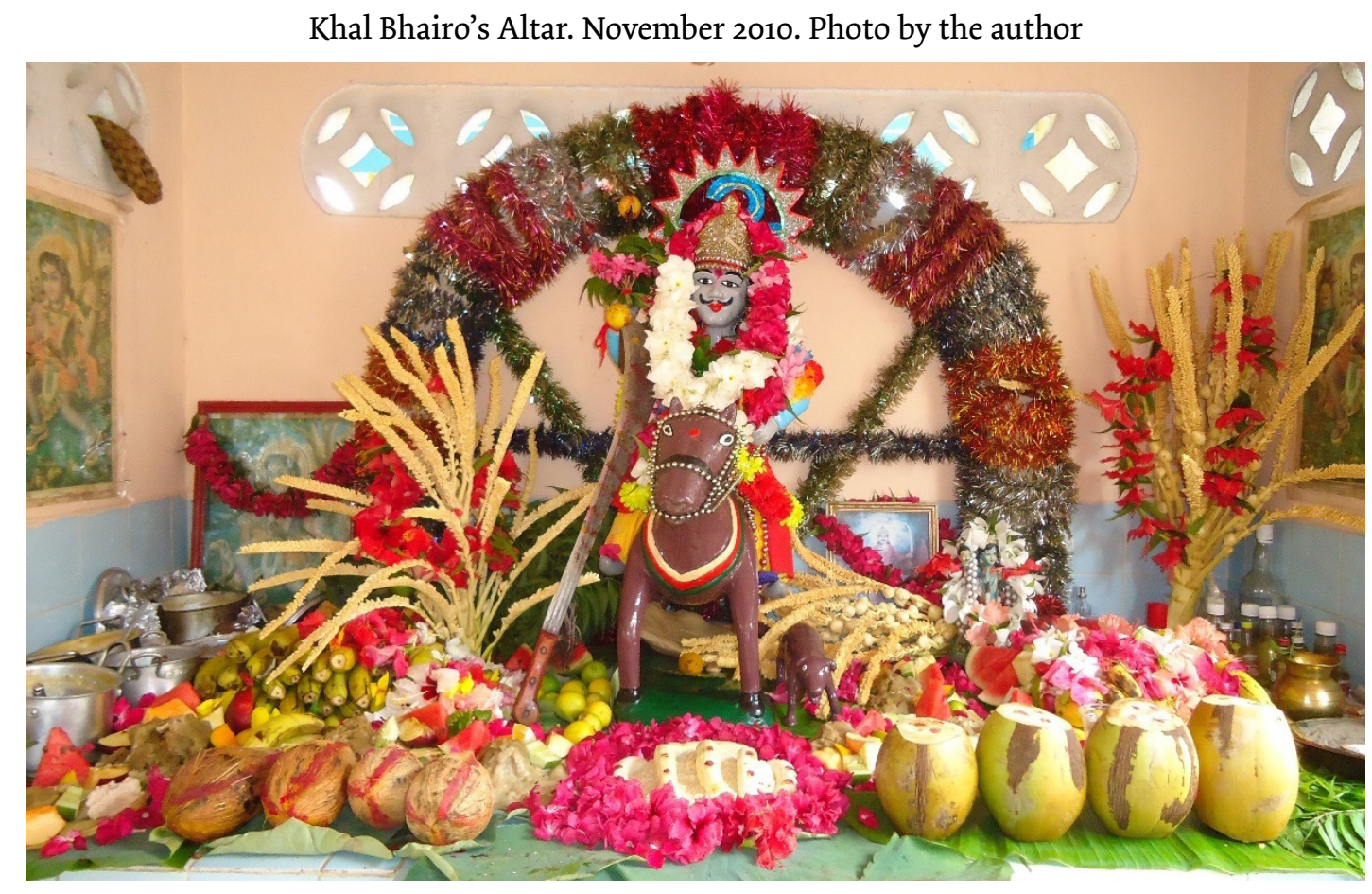

The spiritual matter of sacrificed animals is also consumed by divinities through the murtis. The leftovers, equally energized and blessed, must be ingested by those who offer animals to the gods. In the Small Puja and the Big Puja, all people taking part in the rites must consume the sacrificed cockerels and goats on the day after the conclusion of the festivals. On these occasions, offerings are made by the benefitting temple in the name of all the ritual participants. ${ }^{14}$

Animals to be sacrificed are carefully chosen. They should have a specific colouring - black for Sangani, white for Munispren, and so on - be presentable and not possess any physical defects. Goats and roosters must remain in the temple for at least one night, eating the temple's purer grain. Extra care is taken during the Big Puja, preparations for which last several days. The animals, especially goats, are not only personally selected by priests, they must also remain inside the temple for as long as possible. Tied to wooden posts for much of the day, on release the goats are supervised to stop them wandering into scrubland and injuring themselves.

13 Murtis are not just representations of divinities or inert objects, but instances of the distribution of divine personhood. The first step of the weekly rite in Kali temples consists precisely of the so-called opening of eyes - that is, the invocation of divinities in order for their spiritual forms to install themselves in the murtis during the pujas (Mello 2018).

14 After consummation of the sacrifices, the heads of the animals remain for some minutes in front of the temples of the divinities to which they have been consecrated. Afterwards, they are discarded in a stream. The carcasses are taken to a room further away in order to remove the skins of the cockerels and goats. The person responsible for this process is not the sacrificer and should not have had contact with any stage of the ritual. The meat must be cooked outside the temple by a cook who is also subject to restricted access to certain stages of the ritual. 
In the interstices of relations marked by hierarchies, ${ }^{15}$ therefore, there is also space for entangled relations of care and attention between animals and humans (see Govindrajan 2015). ${ }^{16}$

Caring for animals cultivates the care for divinities. Like the offerings of garlands whose flowers should be resplendent, or fruits which should show no signs of putrefaction, goats and poultry must be in an adequate, suitable and respectable condition - in sum, proper. Then the divinities must accept the offering. Acceptance is connected to divine recognition both of the adequateness of what is offered and of the sincerity of the worship of the devotee or the officiant of the sacrifice. Moreover, it is the animal itself that signals this acceptance in the instant before the consummation of the sacrifice. In other words, sacrifice is only effectively consummated after the acceptance of the deotas, expressed by the animal trembling, three times, after copious amounts of water are poured over its head and body. The trembling does not guarantee acceptance, however, since the sacrificer must decapitate the animal with a single blow. ${ }^{17}$ Shortly below, I present a case in which these factors come to the fore. Before this account, though, I shall quickly describe the care, use and handling of one of the most important sacrificial objects: the machete.

This type of knife, one of the most common work instruments in Guyana, is used to perform everything from simple tasks, like clearing weeds and opening coconuts, to harvesting sugar cane and working in the rice paddies. There are five machetes available to members of Blairmont for sundry uses: cutting grass, slicing, husking and splitting coconuts, chopping down bamboo, opening tins, dicing food, cutting up fabrics and so on. Two machetes are used exclusively for consummating sacrifices, placed on Sundays on the altars of the gods Khal Bhairo and Sangani. Before their utilization, at least three diagonal lines of red (sindoor) powder and turmeric (dye) powder are sprinkled on the blades. These are medicinal substances used to ward off afflictions and impurities. At the moment of sacrifice, this object is manipulated by distinct beings. Firstly, a priest takes the machete from the altar and powders sindoor and dye on the blade, circling it three times around a pan filled with embers to which a sheen of plant resin has been applied moments earlier. The machete is held out to the divine manifestation, which sprinkles water and all the powders onto the machete. Next, the divinity sprinkles the sacrificer himself - who kneels to show submission and receive the blessing - and then rubs the powders on his arms, as well as making a mark with baboot (a dung-based resin) on his forehead. The machete is handed by the divinity to the sacrificer, who circles it three times around the pan. A lemon, previously stuck on the tip of the machete, is divided into four pieces and its juice squeezed towards the four cardinal points by the sacrificer, also in order to repel impurities and afflictions.

Meanwhile, the animals also receive attention. Cockerels are circled three times around the pan as it exhales plant resin, while the pan is circled around the goats. Afterwards, a priest sprinkles the powders over the animal and pours water on its face, waiting for the divinity's acceptance - which, as stated, is not expressed verbally by the manifestation but through the animal's trembling. Finally comes the decapitation. Cockerels are held by an assistant, sufficiently skilled to avoid blood squirting everywhere. Goats, are not held by anyone - unless they are very restless and their rear hooves need to be grabbed. The sacrificer must await the right moment and then, with a single precise blow, decapitate it. The animal's carcass is removed by an assistant while the head is placed in the outside area of the temple, facing the murtis. A candle is lit and an offering of fire made around the head, which remains there for some minutes. In addition, the priest pours water mixed with flowers, neem leaves and the powders into the mouth of the animal. In the conception of the members

15 The sacrifice is not considered something bad for the animals. On the contrary, they are blessed by the deotas and reborn as humans, the highest form of divine creation (according to my interlocutors), in their next existence. It seems no coincidence that debates and interlocutions at Blairmont on the lifedeath-rebirth cycle tend to surface especially in conversations about animal sacrifice.

16 Govindrajan explores animal sacrifice in light of recent developments in multispecies ethnographies and the anthropology of life. I would point out that Godfrey Lienhardt (1961) had already described the complex associations, identifications and relations between supernatural beings, cattle and humans, and indeed this was fundamental to understanding sacrifices among the Dinka.

17 In Martinique too, a successful sacrifice is signalled by execution with one single blow (Desroches 1996: 66). 
of Blairmont, while the sacrificer executes the blow, his arm is guided by the deota to whom the animals are being given. This is the other signal of acceptance, since any failure in the execution of the sacrifice - that is, the non-decapitation of the goat with a single blow - is seen as a consequence of negative and destabilizing emanations from someone impure.

Goat consecrated before the sacrifice. June 2018. Photo by the author

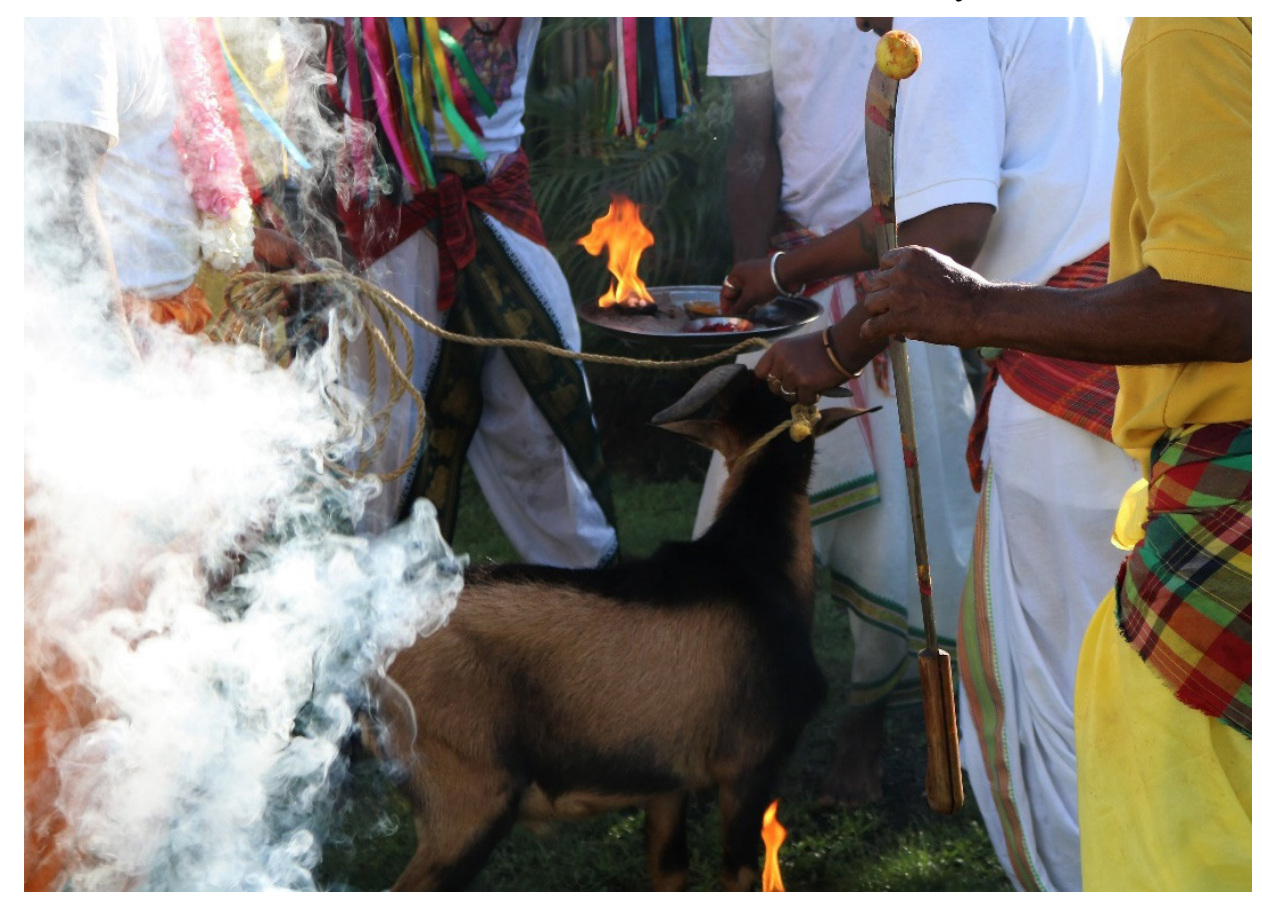

In sum, it is not only the animal who must be proper. Ritual manipulations of objects like the machete aim to repel afflictions and negative influences that can emanate from people's bodies and thoughts. Offerors, officiants and sacrificers must thus keep themselves pure. Hence the importance of adhering to fasting, devoting oneself to the divinities and maintaining one's thoughts focused on them, even though the mere presence of someone impure in the temple can affect everyone. Commenting on the work of Godfrey Lienhardt, Bloch (1992: 35) remarked that the effect of rituals on "peripherical participants" shows that "the boundary between the body of an individual and the wider group is weaker [...] even though the event might be focused on the central actor (the initiate or the patient), all the others present are not onlookers but co-participants." Following the same line of argument, I emphasize that the boundaries between deities, persons, bodies, ritual objects and animals are not given. Mutually constituted and mutually affected, these boundaries are unstable and enable us to think about issues pertaining to the effects of circulation of substances and internal dispositions between distinct beings. To this end, I present a brief ethnographic vignette.

\section{Impregnated machete}

During my field research, four men were alternately responsible for performing sacrifices in Blairmont. Among them, Stumpie frequented the site every week, conducting most of the killings in the Sunday rites. Meanwhile, Eon, who I dealt with more extensively, appeared at the temple only sporadically, usually during the two large annual festivals of Kali worship, the Small Puja and Big Puja, though this intermittent presence did not impede him from exercising his office as a sacrificer. Eon was from a Madrasi family, possessed a robust physical complexion and was about 50 years old, as well as being a cousin of the priest, Bayo. Living more than 100 kilometres from Blairmont, Eon cited the difficulties and costs of travel as the reason for his 
absences from the temple. Although the members of Blairmont recognized these obstacles, they considered his absences excessive. Consequently, the other sacrificers felt that it was unfair Eon was responsible for the sacrifices performed precisely on the most important dates of the annual religious calendar. On the other hand, nobody denied his experience and skill in killing.

As had occurred at the large annual festival, the Big Puja, in 2011, at the 2012 festival Eon arrived at Blairmont on Tuesday, three days before the start of the ceremony, which takes place from Friday to Sunday. As soon as he entered the locale, Eon spread out his mattress, mosquito net and bedding in the temple of the god of sacrifice, and guardian of the goddess Mariamma, Khal Bhairo, sleeping there every night so as to remain close to the god. Over the course of the week, Eon helped with diverse preparations, but since he had little intimacy with the temple's more diligent members, he mostly talked with young people, with myself and with Guyanese arriving from New York especially for the occasion. At night, when the pace of work was less intense, Eon would dressed put on, after bathing, in a new $\mathrm{t}$-shirt with the symbol of Superman and would wander through the temple, telling jokes (poorly received) and trying to initiate conversations (normally without much success). Before sleeping, he meticulously sharpened a new machete (cutlass), acquired by himself especially for the festival.

The three days of the Big Puja ${ }^{18}$ of 2012 were somewhat inauspicious for Eon. On the Saturday, he was unable to decapitate one of the goats with a single blow. On the Sunday, he failed twice, consecutively, in sacrifices for the gods Sangani and Munispren - on one of these occasions, he had to chop three times to separate the animal's head from its body. As observed earlier, sacrifices not consummated with a single blow are inauspicious, signalling the discontent of the divinities. Already on the Saturday evening I had heard speculation as to the causes of the unsuccessful sacrifices: Eon's own errors. On the Sunday, after two further consecutive failures, the negative verdicts gained in strength: Eon was openly criticized by dozens of people. His behaviours were scrutinized, events gone back over and reasons for the failures ventured, always in an accusatory tone, explicitly or implicitly. Among the reasons mentioned for the unsuccessful sacrifices, I highlight:

Eon did not fast properly for twenty-one days.

The thoughts and mind of Eon were not focused sufficiently on the deities. His character and his personal traits attested to his lack of interest and commitment to the religious functions.

Eon was not a true devotee of the goddess. His lack of presence at the temple reflected his lack of devotion.

Instead of using the temple's machetes, Eon choose to handle a new one, which was not sharp enough (his own fault) and which had been brought from an impure place, his home.

To be precise, Eon was subject to a flood of criticism. The summary above captures just a small number of the reproaches and accusations directed at him, although some elements of these comments were recurring. Various people attributed Eon's lack of success to his age, flaws in his character, his exhibitionism (frequently recalling the Superman t-shirt worn during the week), his supposedly unruly life, the fact that he was not a truly religious man, his connections (that is, his kinship with the priest), the latter's leniency in not removing him from his ritual post, and so on. The coup de grâce came from Mariamma herself, manifested in Bayo, the priest and his cousin. As usual, at the end of the festival the goddess convoked the crowd in order to share her view of the festival. Below I reconstruct the goddess's monologue with Eon, based on a few sparse notes taken on my mobile phone:

18 The Big Puja is also known as Karagam Puja, in reference to the sacred vases made especially for the occasion. These are carried in procession through the village where a temple is located in order to absorb, incorporate and remove impurities from people, families, houses and lands throughout the region. 
Mariamma: You certainly know why I'm calling you. You didn't do the right thing and you failed not only with me, but with your brothers. Do you know how important is the sacrifice in my Puja? I couldn't accept all the goats. You never come to my temple, and you don't hear my priest. He told you to come to my temple more often. But you didn't I understand that you cannot here always, but if you were a true devotee of mine these things would never happen. Many of my children do not come here every weekend. But still, they are with me, in their thoughts and feelings. Are you a real devotee? I don't think so. Am I part of your life? Didn't I bless you many times? If you were always thinking of me, I would be in your side, I would guide you, but how can I do that if you do not focus on me? If you don't have a correct life. You affected my entire puja. That's your own and exclusive fault. You know that. I'm not leaving you, I can give you new chances. But you have to earn my confidence. Now, leave and go in peace. Think about your deeds.

The viewpoint of the goddess, conveyed through Eon's cousin, validated and consolidated the criticisms already formulated earlier by other people. ${ }^{19}$ Eon just listened to everything with a resigned air - further proof, in some people's eyes, that he had done something wrong. Among the various criticisms, one element was highlighted by various people: Eon affected the smooth functioning of the festival. And moreover the machete itself. Among other opinions, I present three, sufficiently illustrative for the purposes of this article:

Eon didn't fast properly. He affected the machete. Instead of using the temple's machete, he brought a new one from home. He's responsible for all the disgraces that felt upon us.

(Comment of a priest to other devotees)

Eon caused these disgraces. He affected the machete, the sacrifice, everything, and he offended the goddess. That's why she didn't accepted the goats.

(Comment of a devotee, in dialogue with me)

He put his feelings on things. His thoughts and behaviours affected the things that he touched.

(Comment of a devotee, during a conversation with another women)

Over the course of the Big Puja, Eon had no problems decapitating another fifteen cockerels, along with another five goats, but his blows missed on three occasions. Retrospectively, his conduct and the contact with the altars and the machete became the explanatory cause of his errors. The blows did not follow the expected trajectory because they had been affected, impregnated with the effects of conducts, gestures, feelings, affects and thoughts. Furthermore, precisely because of Eon, the deotas caused the trajectory of the cut to deviate, manifesting their discontent. If responsibility for the failures in the sacrifices ultimately fell on a single individual, this was precisely because the boundaries between material objects, humans and divinities are porous.

19 Ideally, when a person manifests a divinity, he or she falls unconscious, retaining no memory of the actions performed (or the words pronounced) by the divinities during the manifestation. It is in this sense that divinities act as oracles since they verbally express revelations through human vehicles. Elsewhere I have described at length the relationships between oracular revelations, the occurrence of manifestation, and doubts associated with them (Mello 2020). 
The remains of the goat's garland. June 2018. Photo by the author.

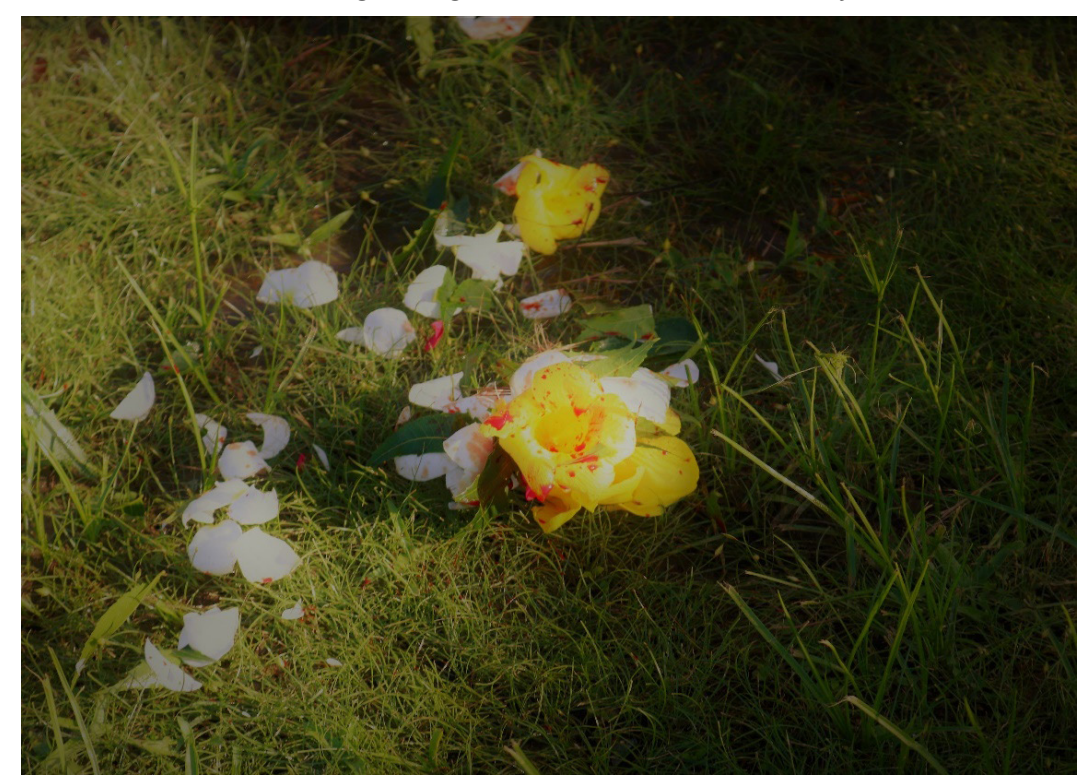

\section{Materiality, affection, personhood}

"The ambit of action of the sacrifice is especially noteworthy," Mauss and Hubert (1964 [1899]: 16-17) emphasized, because it produces a "double effect, one on the object for which it is offered and upon which it is desired to act, the other on the moral person who, desires and instigates that effect." Although these authors reduced the unity of sacrifice to a procedure through which communication is established between the worlds of the sacred and profane, projecting a universalism open to contestation (see de Heusch 1985; Panagiotopoulos 2018), ${ }^{20}$ their emphasis on the irradiations - or more precisely, the effects - of sacrificial acts is worth retaining. As Robbins (2017) has suggested, Mauss and Hubert's essay anticipates recent anthropological debates on the practices of religious mediation. Given that, in diverse contexts, deities become present through distinct types of mediating acts (verbal utterances, objects handled at rituals, musical and bodily performances and so on), mediation establishes both approximations and distances between the divine and the mundane, comprising something essential in religious life and social life as a whole. Ultimately, relations of prestation and counterprestation are bound up with the problem of presence.

In Kali worship, divinities are present in murtis and other artefacts, on altars and in the bodies of religious specialists, distributing their power (shakti) within a particular ambience. The manipulation and consecration of objects like the machete show the importance of paying attention to materiality in the mediation practices between humans and divinities. Daniel Miller (2002) highlights the fact that in many contexts material objects are conceived less through their attributes and more through the place they occupy in an exchange or a ritual. Consequently, the "implications of artefacts" can alter simply through the introduction of these artefacts in a new order. The machete brought by Eon from his home can be thought of precisely in these terms, since, compared to others, he possessed an ephemeral relationship with the temple, with the altar of Khal Bhairo and with the purposes of its use. Although the blades of the temple's machetes show clear signs of wear, their constant use in the temple makes them comparatively more effective, imbued with greater force, so to speak.

20 Other critical points in Mauss and Hubert's work include the prominence of Vedic sacrifice in their conceptual schema, understood through JudeoChristian canons (Bloch 1992: 28-29), and the presence of evolutionist precepts in their analytic schema (de Heusch 1985: 15). 
Well before the 'material turn' in anthropology, and in the anthropology of religion in particular (Hazard 2013), Evans-Pritchard (1956) had already called attention to the fact that among the Nuer, spears - both those used in warfare and those used for fishing - were far more than a tool, amounting to true parts and extensions of persons. ${ }^{21}$ Following the path indicated by Evans-Pritchard, we could ask apropos the case being studied here: machetes are extensions of whom, exactly? Deities, the officiant of the sacrifice, or both? Considering that the gods and goddesses guide the course of the blows struck by the sacrificer and the latter utilizes an object kept on the altar of a god associated with the sacrifice, the machetes can also be conceived as an extension of the deities, their manifestations and the murtis, since the artefactual bodies of the divinities are distributed during the rites, permeating the people all around.

In his already classic reformulation of how art objects, images, icons and the like should be treated as persons in the context of an anthropological theory of art - that is, as sources and targets of social agency - Gell (1998) argues against both aesthetic and symbolist approaches. Proposing a new anthropological theory of art instead, inspired by other existing anthropological theories, in diverse passages of Art and Agency Gell makes use of reflections on the notion of the person - evident in his diverse references to Marcel Mauss, Roy Wagner and Marilyn Strathern, as well as to monographs on exchange systems like kula and studies of Hinduism, especially those relating to idolatry. In fact, the diverse formulas and schemas set out in the initial chapters of his work are nuanced by the analysis of abundant ethnographic material (Cesarino 2017; Mello 2018), including on topics relating to 'religion.'

As Gell remarks, the attention paid to idolatry and volt sorcery, for example, aims to desacralize the attitude of an aesthetic, almost religious, veneration of art works, as well as foment a desacralization of the concept of the individual. The ideas implicit to the concept of the individual not only result in dichotomies, they also permeate theoretical propositions relating to art - as in the supposition that artistic creation depends above all on individual genius. Thus, it is indispensable to return to debates relating to the person, paying sufficient attention, following Mauss, to the limits and boundaries of persons, questioning the premise that individuals are clearly identifiable, self-contained and delimited. For Gell, diverse ethnographic instances suggest that persons are not confined to specific sociotemporal coordinates, but are distributed in ambiences, objects, minds, bodies and material traces.

Not without reason, Gell's inquiries into agency have elicited criticisms of his emphasis on material objects in detriment to an analysis of the flows of materials (Ingold 2011) and of his supposed incapacity to revise more deeply Western understandings of persons and things in considering material objects as secondary agents (Henare et al. 2007; Leach 2007). In part, this is due to the limitations inherent to Gell's posthumous work, including the absence of a more explicit debate on the notion of the person in India, which is indeed somewhat surprising given the author conducted fieldwork on the subcontinent. On the other hand, the ethnographic material analysed and presented by Gell concerning the physical fragments decoupled from distributed persons, as in the case of volt sorcery, and the forms of tactile contact established by the exchange of gazes between Hindu idols and worshippers (see also Babb 1981; Eck 1998; Mello 2018), offer us interesting clues to think about a topic seldom explored either by Gell or by diverse studies on material objects, materialities and materials: the circulation and distribution of substances between agents who transact.

Along these lines, Marriott's work (1976) on the processes of transferring essences and bodily substances between human and non-human persons seems to me fundamental. The author proposes that Hindu society (and Indian society as a whole) developed a transactional thought characterized by explicit and institutional preoccupations with the given and the received in the universes of kinship, work and religion.

\footnotetext{
21 de Heusch (1985: 6-15) convincingly argues that in Nuer Religion Evans-Pritchard inserts a series of semantic alterations into his translations of native vocabulary to the point of distorting elements of his research in order to adapt it to the parameters of Judeo-Christian theology.
} 
From the Western viewpoint, Hindu thought is especially oriented towards biological substantialism and hierarchical classification. Hindu's systematic particularism and monism, however, need to be explored beyond the Western philosophical burdens of universalism, dualism and individualism, since the Indian notions point to conceptions about the divisibility of persons.

Hindu thought concerning transactions differs from Western sociological and psychological thought since it does not presume the separability of actors from their actions. In Indian modes of thought, what happens between actors is connected to the processes of mixture and separation happening between them, meaning that their particular natures are conceived as the causes and outcomes of particular actions. Codes of action or conduct, in turn, are conceived to be naturally incorporated into the actors and substantialized in the things that flow and pass between them. The separability of the actions of agents into code and substance, a typically Western premise, is absent from Hindu thought. Code and substance are inseparable in this case, hence the author's use of the notion of code-substance or substance-code. Citing Marriott:

Persons - single actors - are not thought in South Asia to be 'individual,' that is, indivisible, bounded units [...] Instead, it appears that persons are generally thought by South Asians to be 'dividual' or divisible. To exist, dividual persons absorb heterogeneous material influences. They must also give out from themselves particles of their own coded substances - essences, residues, or other active influences - that may then reproduce in others something of the nature of the persons in whom they have originated. Persons engage in transfers of bodily substancecodes through parentage, through marriage, and through services and other kinds of interpersonal contacts. They transfer coded food substances by way of trade, payments, alms, feasts or other prestations. Persons also cannot help exchanging certain other coded influences that are thought of as subtler, but still substantial and powerful forms, such as perceived words, ideas, appearances, and so forth. Dividual persons, who must exchange in such ways, are therefore always composites of the substance-codes that they take in (Marriott 1976:111).

It is essential to stress that although Marriott refers to human persons in this excerpt, he suggests that virtually the same happens with other categories of beings like deities. The author also cites ethnographies that emphasize how men and gods are conceived in rural areas of India as mutually continuous, not separated by distinctions like sacred and profane, spirit and matter.

In summary, for Marriott the transformations that occur within actors also involve transactions between parts of actors, while transactions between actors can lead to transformations of these actors. Transformations and transactions, however, must be understood as part of a single process. In transactions, actors and their actions change constantly though recombinations of their parts. Actors and their interactions are never separate from each other; they change together, including because the circulations and combinations of particles of the codes-substances are occurring continuously.

Marriott's analysis contains a series of problems, being somewhat formalist and presuming a dichotomy, as though substances were immutable and permanent in the West and inherently fluid and transformative in India or South Asia (see Busby 1997; Carsten 2000; Nabokov 2000). Nevertheless, I believe that his conceptualization provides space for thinking about the permeability of persons to bodily substances originating from other persons (Daniel 1984). As Pina Cabral (2018; 2019) has recently noted, differently to theoretical models centred on the modes through which individual entities form part of something without losing their essence and individuality, the concept of dividual points to the constitutive character of mutual participations in which things and beings can be related without necessarily possessing clearly defined limits, even when they share some kind of essence. In sum, "dividuality and its related concept of partibility involve a questioning of the very processes of generating of the entities that enter into a relation. Therefore, the person is seen in terms of a dynamic of constant emergence, not as a naturally given entity existing once and for all" (Pina-Cabral 2018: 438). 
Pina-Cabral's references to dividuality and partibility take into account the analytic transpositions of the concept formulated by Marriott (1976) to the Melanesian context, the ethnographic region to which the concept is normally linked thanks to the impact of the work of Strathern (1988). ${ }^{22}$ My intention in turning back to Marriott to think about certain dimensions of Kali worship in Guyana neither proceeds in this direction, nor attempts to establish continuities between India and Guyana taking the Hindu religious sphere as a metonym for 'Indo-Caribbean culture. ${ }^{23}$ It is not a question, therefore, of postulating essences but of testing the possibilities for incorporating into Caribbean scholarship perspectives produced elsewhere and, principally, for re-evaluating major themes of this production in light of native categories.

It would be necessary to investigate in more detail the reasons why some clues offered by ethnographic studies conducted in India have attracted little interest among Caribbean scholars (see, however, Khan 1994 and Jayaram 2006), including those scholars undertaking research among Indo-Caribbean populations. This can be partly explained, I would suggest, by the fact that the heterogeneity, complexity and historicity of the Caribbean prevented, from very early on, the application of the conceptual devices of compartmentalization, encompassment and framing to the realities of Caribbean collectives. Thus, no gatekeeping concept, like honour and shame in the Mediterranean or hierarchy in India (see Trouillot 1992), ${ }^{24}$ was able to take root in the Caribbean.

Linked to this fact, and following Trouillot's argument concerning the profoundly historical character of the Caribbean, the processes of migration, integration with receiving societies, and asymmetries of power during and after the indentured labour system, as well as interethnic contacts especially with Afro-Caribbean populations, had a considerable impact on central institutions originating from India, including the caste system. ${ }^{25}$ In other words, the migration from India to the Caribbean and the living conditions in the plantations weakened notions relating to ritual purity. Taboos and avoidances lost some of their force since members of distinct castes and groups from diverse origins now lived side-by-side (Bisnauth 2000; Jayawardena 1966; Look Lai 1993; Laurence 1994; Moore 1977; Munasinghe 2001; Smith \& Jayawardena 1996 [1967]). As the years passed, the identification of Indo-Guyanese people with specific castes faded and was continually condemned for promoting distinctions (allegedly) given by birth. Among my interlocutors, a person's moral quality is evaluated by his or her acts, including by the willingness to live in an egalitarian form with others, and not so much by inherited attributes.

While the emphasis on the changes to institutions central on the Indian subcontinent seems to me sound, an emphasis solely on those processes of transformation occurring at a macro-analytic scale - that is, the outcomes of broader historical processes - can lose sight of local perceptions of mixtures and heterogeneities.

\footnotetext{
22 Strathern recognizes the originality of Marriott's work and her own debt to it. In her work, the concept of dividual acquires other dimensions, including as a result of the important debate with Wagner's notion of fractality (1991). For an interesting analysis of the differences in the notions of the person in Southern India and Melanesia, see Busby (1997).

23 Symptomatically, the first publications based on ethnographic studies with Caribbean populations, which emerged in the 19605 and 705 (Horowitz 1963 ; Horowitz \& Klass, 1961; Klass 1961; Schwartz 1965; Singer \& Araneta 1967; Rauf 1974) were primarily concerned with showing how Indo-Caribbean religious practices and identities, especially Hindu, were, and continued to be, fundamental to the perpetuation of the cultural distinctiveness of these groups (see Vertovec 1991).

24 To cite the author: "Gatekeeping concepts are so-called 'native' traits mystified by theory in ways that bound the object of study. They act as theoretical simplifiers to restore the ethnographic present and project of timeless culture. Gatekeeping has never been successful in the Caribbean. Here, heterogeneity and historicity opened up new vistas, deflecting energies from theoretical simplification" (Trouillot 1992: 22).

25 As Jayaram (2006) notes, investigations into caste among diasporic Hindu communities have frequently been phrased in terms like retention and change. In general, the existence of an ideal type of caste system is postulated and a categorical response is sought concerning the maintenance, or not, of this system outside India. Khan (1994: 246) had already highlighted this issue previously, as well as demonstrating that although caste, as a structuring element of hierarchies, is not present in Trinidad, the notion of jhutta - food or drink polluted by being partially consumed by a person - is an important dimension of the Indo-Trinidadian cultural repertoire, deriving its diverse meanings from notions of pollution associated with caste identities.
} 
Khan (2004) seems particularly interested in this when, in her study of Trinidad and Tobago, she focuses on what she calls "metaphors of mixture": practices, discourses and events in which the foundational theme of mixture, especially interethnic, is communicated through analogies, metonymies, images and demands articulated by means of terms like purity, impurity, orthodoxy, heterodoxy and authenticity.

Khan focuses especially on the disputes over the legitimization of religious practices and knowledge in asymmetric power contexts. For this reason, the author does not predefine what is religion but rather scrutinizes the understandings, conceptions and native categories of religion. In the case under discussion here, the stigmatization of Kali worship in Guyana forms the backdrop to a series of discourses on sacrifice. Two points should be emphasized, though. Firstly, the foundation myths of Kali worship are not just responses to disputes for power, nor raw material for attempts to legitimize practices considered morally suspect. At a microscopic level - and this is the second point I wish to bring forth - the circulation of substances like blood, a fundamental vector of connections between persons with a distinct ontological status (Carsten 2013), the distribution of divine forces and powers in the rituals, and the permeability of human and non-human persons are all of fundamental importance to worshippers of Kali since they generate diverse effects.

In holding Eon responsible for the failures in the sacrifices, members of Blairmont temple did much more than search for a scapegoat (with apologies for the pun). Initial accusations, which soon became rubberstamped verdicts, including due to the view expressed by the manifestation of the goddess Mariamma, were consistent with the premise that, rigorously speaking, no being, or object, is separate from other beings or objects. Far from being a singular and unitary event, animal sacrifice forms part of a heterogenous set of practices. Sacrifice, therefore, deserves ethnographic attention because its simple occurrence is a central trope for examining a highly diverse set of practices (see Mayblin \& Course 2014). ${ }^{26}$

In the case of Kali worship, then, it is indispensable to situate sacrifice within practices of animal care, the handling of ritual artefacts, and diverse other relations between deities and humans. It is notable that the machete utilized by Eon absorbed substances, feelings and emotional states from the sacrificer. When people sought to explain the failure of three sacrifices, Eon's quality of devotion and purity of intention were the target of diverse remarks. The sacrificial act involved intentionality, the sacrificer's self. Similarly to the case studied by Samanta (1994), his body - and consequently the body of the goats - can be conceived as a site of transformations in perspectives, states of consciousness, attitudes and moral essences. Sacrifice thus assumes a specific configuration in each situation, irreducible to the presupposition that two or more separate and self-contained entities transact. On the contrary, the boundaries between different entities are not only not given, they can produce transformations via the channelling and flow of vital forces. Humans, deities, animals and material objects participate in each other through mutual and complex chains of permeability.

Received: September 23, 2019

Approved: January 07, 2020

Translated by David Rodgers

\footnotetext{
26 Mayblin \& Course (2014: 313-314) suggest that analyses of sacrifice should not be limited to the domain of ritual and may include studies of autobiographical narratives of personal suffering, or as a quality in political activism, for instance. I am aware that an emphasis on rituals can imply artificial separations between 'ritual' and 'mundane,' 'religious' and 'secular.' I emphasize, though, that my research focused on a specific temple, developing into other spheres of life of those people with whom I lived more intensely. Although I deliberately did not set out to centre my research on villages, I believe that questions relating to the exchange of substances, pollution and commensality are fundamental to Indo-Guyanese everyday life.
} 


\section{References Cited}

BABB, Lawrence. 1981. "Glancing: visual interaction in Hinduism”. Journal of Anthropological Research, 37(4): 387-401.

BAHADUR, Gaiutra. 2014. Coolie woman. The odyssey of indenture. Chicago: The University of Chicago Press. BISNAUTH, Dale. 200o. The settlement of Indians in Guyana, 1890-1930. Leeds: Peepal Tree Press.

BLOCH, Maurice. 1992. Prey into hunter. The politics of religious experience. Cambridge: Cambridge University Press.

BRUBAKER, Richard L. 1978. The ambivalent mistress. A study of South Indian village goddesses and their religious meaning. PhD Dissertation, Faculty of the Divinity School, University of Chicago.

BUSBY, Cecilia. 1997. "Permeable and partible persons: a comparative analysis of gender and body in South India and Melanesia". Journal of the Royal Anthropological Institute, 3(2): 261-278.

CARSTEN, Janet. 2000. Culture of relatedness: new approaches on the study of kinship. Cambridge: Cambridge University Press.

. 2013. "Introduction: blood will out". In: J. Carsten (ed.), Blood will out. Essays on liquid transfers and flows. London: Willey Blackwell/ Royal Anthropological Institute. pp. 1-23.

CESARINO, Pedro. 2017. "Conflitos e pressupostos na antropologia da arte. Relações entre pessoas, coisas e imagens". Revista Brasileira de Ciências Sociais, 32(3): 1-17.

CONNOLY, Jonathan. 2019. "Indenture as compensation: state financing for indentured labour migration in the era of emancipation". Slavery \& Abolition, 40(3): 448-471.

DANIEL, E. Valentine. 1984. Fluid signs. Being a person in the Tamil way. Berkeley: University of California Press.

DESROCHES, Monique. 1996. Tambours des dieux. Musique et sacrifice d'origine tamoule en Martinique. Montréal: L’Harmattan Inc.

ECK, Diana L. 1998 [1981]. Darsan. Seeing the divine image in India. New York: Columbia University Press. EVANS-PRITCHARD, E. E. 1956. Nuer religion. Oxford: Oxford University Press.

GELL, Alfred. 1998. Art and agency. Oxford: Clarendon Press.

GOVINDRAJAN, Radhika. 2015. "The goat that died for the family'. Animal sacrifice and interspecies kinship in India's Central Himalayas". American Ethnologist, 42(3): 504-519.

HAZARD, Sonia. 2013. "The material turn in the study off religion". Religion and Society, 4(1): 58-78.

HENARE, Amiria; HOLBRAAD, Martin \& WASTELL, Sari. 2007. Thinking through things: theorising artefacts ethnographically. London: Routledge.

HEUSCH, Luc de. 1985. Sacrifice in Africa. A structuralist approach. Manchester: Manchester University Press. HOROWITZ, Michael M. 1963. "The worship of South Indian deities in Martinique". Ethnology, 2(3): 339-346. . \& KLASS, Morton. 1961. "The Martiniquian East Indian cult of Maldevidan”. Social and Economic Studies, 10(1): 91-100.

INGOLD, Tim. 2011. "Materials against materiality". In: Being alive. Essays on movement, knowledge, and description. London: Routledge. pp. 19-32.

JAYARAM, N. 2006. "The metamorphosis of caste among Trinidad Hindus". Contributions to Indian Sociology, 4O(2): 143-173.

JAYAWARDENA, Chandra. 1966. "Religious belief and social change: aspects of the development of Hinduism in British Guiana”. Comparative Studies in Society and History, 8: 211-240,

KHAN, Aisha. 1994. "Juthaa in Trinidad: food, pollution, and hierarchy in a Caribbean diasporic community". American Ethnologist, 21(2): 245-269. . 2004. Calallo nation. Metaphors of race and religious identity among South Asians in Trinidad. Durham: Duke University Press. 
KLASS, Morton. 1961. East Indians in Trinidad. A study of cultural persistence. New York: Columbia University Press.

LAURENCE, K. O. 1994. A question of labour. Indentured immigration into Trinidad and British Guiana, 1875-1917. Kingston: Ian Randle Publishers.

LEACH, James. 2007. "Differentiation and encompassment: a critique of Alfred Gell's theory of the abduction of creativity". In: A. Henare, M. Holbraad, S. Wastell (eds.), Thinking through things: theorising artefacts ethnographically. London: Routledge. pp. 167-188.

LIENHARDT, Godfrey. 1961. Divinity and experience. The religion of the Dinka. Cambridge: Clarendon Press.

LOOK LAI, Walter. 1993. Indentured labor, Caribbean sugar. Chinese and Indian migrants to the British West Indies, 1838-1918. Baltimore: John Hopkins University Press.

MARRIOT, McKim. 1976. "Hindu transactions: diversity without dualism”. In: B. Kapferer (ed.), Transaction and meaning. Directions in the anthropology of exchanging and symbolic behavior. Philadelphia: Institute for the Study of Human Issues, pp. 109-142.

MAUSS, Marcel; HUBERT, Henri. 1964 [1899]. Sacrifice: its nature and function. Chicago: The University of Chicago Press.

MCNEAL, Keith. 2011. Trance and modernity in the Southern Caribbean. African and Hindu popular religions in Trinidad and Tobago. Gainesville: University Press of Florida.

MAYBLIN, Maya; COURSE, Magnus. 2014. “The other side of sacrifice: introduction”. Ethnos: Journal of Anthropology, 79(3): 307-319.

MELLO, Marcelo. 2020. "Mimesis, poder e dúvida: divindades hindus e espíritos de colonizadores na Guiana”. Horizontes Antropológicos, 56: 57-86.

. 2018. "Murtis em movimento: relações entre pessoas, coisas e divindades em um templo hindu na Guiana”. Mana - Estudos de Antropologia Social, 24(3): 103-130.

. 2014. Devoções manifestas. Religião, pureza e cura em um templo da deusa hindu Kali na Guiana. Tese (Antropologia Social). Rio de Janeiro: Programa de Pós-Graduação em Antropologia Social, Museu Nacional, Universidade Federal do Rio de Janeiro.

MOORE, Brian L. 1977. "The retention of caste notions among the Indian immigrants in British Guiana during the nineteenth century". Comparative Studies in Society and History, 19(1): 96-107.

MILLER, Daniel. 2002. "Artifacts and the meaning of things". In: T. Ingold (ed.), Companion Encyclopaedia of Anthropology. London: Routledge. pp. 400-419.

MUNASINGHE, Viranjini. 2001. Callaloo or tossed salad? East Indians and the cultural politics of identity in Trinidad. Ithaca: Cornell University Press.

NABOKOV, Isabelle. 200o. Religion against the self. An ethnography of Tamil rituals. Oxford: Oxford University Press.

PANAGIOTOPOULOS, Anastasios. 2018. "Food-for-words. Sacrificial counterpoint and oracular intimacy in Cuba". Hau - Journal of Ethnographic Theory, 8(3): 474-487.

PINA-CABRAL, João de. 2019. "My mother or father: person, metaperson, and transcendence in ethnographic theory". Journal of the Royal Anthropological Institute, 25: 303-323.

. 2018. "Modes of participation". Anthropological Theory, 18(4): 435-455.

RAUF, Mohammad A. 1974. Indian village in Guyana. A study of cultural change and ethnic identity. Leiden: E. J. Brill.

ROBBINS, Joel. 2017. "Keeping god's distance: sacrifice, possession, and the problem of religious mediation". American Ethnologist, 44(3): 464-475.

SAMANTA, Suchitra. 1994. "The 'self-animal' and divine digestion: goat sacrifice to the goddess Kali in Bengal". The Journal of Asian Studies, 53(3): 779-803. 
SINGER, Philip; ARANETA, Enrique. 1967. "Hinduization and creolization in Guyana: the plural society and basic personality”. Social and Economic Studies, 16(3): 221-236.

SMITH, Raymond. 1959. "Some social characteristics of Indian immigrants to British Guiana". Population Studies, 13: 34-39.

SMITH, Raymond; JAYAWARDENA, Chandra. 1996 [1967]. "Caste and social status among the Indians of Guyana”. In: R. Smith (ed.), The matrifocal family. Power, pluralism, and politics. Routledge: New York. pp. 111-142.

STEPHANIDES, Stephanos; SINGH, Karna. 2000. Translating Kali's feast. The goddess in Indo-Caribbean ritual and fiction. Amsterdam: Rodopi.

STRATHERN, Marilyn. 1988. The gender of the gift. Problems of women and problems with society in Melanesia. Berkeley: University of California Press.

SCHWARTZ, Barton. 1965. "Extra-legal activities of the village pandit in Trinidad and Tobago". Anthropological Quarterly, 38: 62-71.

TINKER, Hugh. 1993 [1973]. A new system of slavery. The export of Indians overseas, 1830-1920. London: Hansib. TROUILLOT, Michel-Rolph. 1992. "The Caribbean region: an open frontier in anthropological theory". Annual Review of Anthropology, 21: 19-42.

VERTOVEC, Steven. 1996. '“Official' and 'popular' Hinduism in the Caribbean: historical and contemporary trends in Suriname, Trinidad, and Guyana”. In: D. Dabydeen \& B. Samaroo (eds.), Across the dark waters. London: MacMillam. pp. 108-130.

. 1991. "East Indians and anthropologists: a critical review". Social and Economic Studies, 40(1): 133-169.

WAGNER, Roy. 1991. “The fractal person”. In: M. Strathern \& M. Godelier (eds.), Big men and great men: personifications of power in Melanesia. Cambridge: Cambridge University Press. pp. 159-173.

WILLIAMS, Brackette. 1990. "Dutchman ghosts and the history mystery: ritual, colonizer, and colonized interpretations of the 1763 Berbice slave rebellion”. Journal of Historical Sociology, 3(2): 133-165.

YOUNGER, Paul. 2010. New homelands. Hindu communities in Mauritius, Guyana, Trinidad, South Africa, Fiji and East Africa. Oxford: Oxford University Press.

Marcelo Moura Mello

Assistant Professor - Department of Anthropology and Ethnology

Federal University Federal da Bahia

https://orcid.org/oooo-0002-9460-2824

Email:mmmello@gmail.com 